This item was submitted to Loughborough's Research Repository by the author.

Items in Figshare are protected by copyright, with all rights reserved, unless otherwise indicated.

\title{
A new populism index at work: identifying populist candidates and parties in the contemporary Greek context
}

PLEASE CITE THE PUBLISHED VERSION

https://doi.org/10.1080/23745118.2016.1261434

PUBLISHER

(C) Taylor \& Francis

VERSION

AM (Accepted Manuscript)

\section{PUBLISHER STATEMENT}

This work is made available according to the conditions of the Creative Commons Attribution-NonCommercialNoDerivatives 4.0 International (CC BY-NC-ND 4.0) licence. Full details of this licence are available at: https://creativecommons.org/licenses/by-nc-nd/4.0/

\section{LICENCE}

CC BY-NC-ND 4.0

\section{REPOSITORY RECORD}

Stavrakakis, Yannis, loannis Andreadis, and Giorgos Katsampekis. 2019. "A New Populism Index at Work: Identifying Populist Candidates and Parties in the Contemporary Greek Context”. figshare. https://hdl.handle.net/2134/31993. 
TITLE

\section{A NEW POPULISM INDEX AT WORK: IDENTIFYING POPULIST CANDIDATES AND PARTIES IN THE CONTEMPORARY GREEK CONTEXT}

AUTHORS

(1) Yannis Stavrakakis

School of Political Sciences,

Aristotle University of Thessaloniki

46 Egnatia St., Thessaloniki, 54625, GREECE

Tel. +30-2310991993, e-mail: yanstavr@yahoo.co.uk

(2) Ioannis Andreadis

School of Political Sciences,

Aristotle University of Thessaloniki

46 Egnatia St., Thessaloniki, 54625, GREECE

Tel. +30-2310991992, e-mail: john@ polsci.auth.gr

(3) Giorgos Katsambekis (Corresponding author)

School of Political Sciences,

Aristotle University of Thessaloniki

46 Egnatia St ., Thessaloniki, 54625, GREECE

Tel. +30-6976058148, e-mail: giorgos_bek@hotmail.com 


\section{AUTHOR BIOGRAPHIES}

Yannis Stavrakakis studied political science in Athens and discourse analysis at Essex, where he completed his PhD. He has worked at the Universities of Essex and Nottingham and is currently Professor of Political Discourse Analysis at the Aristotle University of Thessaloniki. He is the author of Lacan and the Political (Routledge, 1999) and The Lacanian Left (Edinburgh University Press/ SUNY Press, 2007), coauthor of Populism, Anti-Populism and Crisis (Nefeli, 2012) and co-editor of Discourse Theory and Political Analysis (Manchester University Press, 2000). He served as Principal Investigator of the research project POPULISMUS: $\underline{\text { www.populismus.gr }}$

Ioannis Andreadis is Assistant Professor of Quantitative Methods in the Social Sciences at the School of Political Sciences of the Aristotle University Thessaloniki. He is a member of the steering committee of the Comparative Candidate Survey project. He is a national collaborator for the Comparative Study of Electoral Systems for Modules 3 and 4 and a founding member of the Hellenic National Election Studies. He specializes in web surveys and is the designer of the Voting Advice Application HelpMeVote.eu. He has (co-) authored several articles published in journals, books and conference proceedings. For more details please visit http://www.polres.gr/en/andreadis/

Giorgos Katsambekis is a postdoctoral researcher at the Aristotle University of Thessaloniki. He has worked as a doctoral researcher in the EU-funded research project 'POPULISMUS: Populist Discourse and Democracy’ (2014-2015). His articles and reviews have appeared in a variety of journals, such as the Journal of 
Political Ideologies, Constellations, European Political Science and Political Studies Review. He recently co-edited the collective volume Radical Democracy and Collective Movements Today. The Biopolitics of the Multitude versus the Hegemony of the People (Ashgate, 2014).

\section{ACKNOWLEDGMENTS}

This work partly draws on research supported by the European Social Fund (European Union) and National Funds (Greece) - Action 'ARISTEIA II' within the framework of the Operational Programme 'Education and Lifelong Learning' under grant no. 3217. 


\begin{abstract}
Interrogating available indexes from a discourse-theoretical point of view, this paper utilizes a reformulated populism index in order to identify populist parties. In particular, the index is applied in a candidate survey carried out in Greece in 2015. Findings indicate that this index allows for a clear differentiation between populist and non-populist parties. Based on candidate attitudes, SYRIZA and ANEL belong to the first group whereas New Democracy, PASOK and River to the second. The examination of additional survey items reveals a clear ideological division within the populist camp: right-wing populism is exclusionary, while left-wing populism more inclusive and pluralist.
\end{abstract}

\title{
KEYWORDS
}

Candidates; Discourse; Greece; Populism; Surveys 


\section{Introduction}

In this paper we present the findings of research designed to test if and how populist attitudes among political elites can be measured by including a battery of items in a survey questionnaire producing particular indexes. In particular, we purport to enrich the work published in the available populism literature with insights from a predominantly discursive approach inspired by the so-called Essex School. We have thus employed statements conducive to the two criteria of populist identification highlighted by this theoretical orientation; in particular, we explore whether attitudes (a) are constructed around the nodal point 'the people', and (b) reflect a perception/representation of society as divided between two hostile camps: the people against the elite. Our first research question is the following: Can we use this theoretically informed battery and the resulting populism index to discriminate between populist and non-populist parties? A second one follows: Can we use these and additional survey items to discriminate between left-wing and right-wing populism?

In the 2015 Greek Candidate Survey we have thus asked respondents to indicate their level of agreement with a series of statements on a five point Likert scale and we have used their responses to create an index of populist attitudes for each respondent. Then we have summarized these populism indexes by political party in order to create a populism index for each political party. In order to test our research questions/hypotheses, we first register reflexively the existing prevailing wisdom separating Greek political parties into populist and non-populist or anti-populist. Then we compare our survey-based populism indexes with this standpoint. If the index associated with a populist party is significantly stronger than the index pertaining to a 
non-populist party, then our battery could be seen as a promising way of measuring populism. The findings presented in this paper are based on the Greek part of the Comparative Candidate Survey, which is conducted as a web survey. Unfortunately, the dataset does not offer the opportunity for a comparative analysis between countries, but it can serve as a useful pilot study to check the quality of the statements used in the populism battery.

The results produced by the Candidate Survey provide crucial information regarding the supply side of populist attitudes in the Greek context, since candidates actively construct and/or transmit appeals to the electorate, (re)producing interpellations in a more or less coherent manner, depending on the political party they represent. Measuring candidates' populist attitudes has not been attempted in the existing bibliography - which has focused on measuring party populism (Hawkins 2010; Pauwels 2011; Rooduijn et al 2014; Rooduijn and Pauwels 2011) and citizens' populist attitudes (Hawkins et al 2012; Akkerman et al 2013; Spruyt et al 2016). Doing so could provide valuable insights into what may be not just an additional aspect, but the missing link connecting the two aforementioned dimensions, translating and 'embodying' party ideology in accessible ways able to potentially influence citizens' attitudes and vice-versa.

\section{State of The Art: The Development of the Populist Attitudes Battery}

The first version of our survey items used to measure populist attitudes have been developed by Kirk Hawkins and Scott Riding (2010). Following their argument that populism is not an ideology, but a worldview that 'identifies Good with a unified will 
of the people and Evil with a conspiring elite' they have tried to develop questions that incorporate both the core ideas of populism and the language in which they are expressed. Their first battery of populist attitude items was included in the 2008 AmericasBarometer surveys conducted by the Latin American Public Opinion Project at Vanderbilt University. The questionnaire included six items asking respondents to indicate their level of agreement with a statement. The overall focus of this attempt was to measure populist attitudes as the expression of a struggle between the 'pure' people and the 'corrupt' elite.

In the same paper Hawkins and Riding use a subsample of 1,000 respondents from the 2008 Cooperative Congressional Elections Studies (CCES), an Internet survey conducted by Yougov/Polimetrix and the 2008 Utah Colleges Exit Poll (UCEP) and a sample of 950 respondents that was collected during the November 2008 general elections. The same datasets and a similar analysis were used later in a paper by Hawkins, Riding and Mudde (2012).

Building on the aforementioned studies, Akkerman, Mudde, and Zaslove (2013) have tested a battery of items to measure populist attitudes and to investigate whether these attitudes can be linked with party preferences on a representative data set of 586 Dutch respondents. This battery consists of three types of questions with a target to measure (a) populist attitudes, (b) pluralist attitudes, and (c) elitist attitudes. Based on the findings of this paper a group of scholars has proposed six populist attitudes items for the CSES Module 5 (2016-2021).

\title{
Enter the Essex School: discourse theory and surveys
}

\author{
Populist vs. non-populist profiles
}


The way we have chosen to formulate our questions attempts to facilitate further an evolving dialogue between the 'new mainstream' in populism studies - comprising the aforementioned work by Mudde, Hawkins, etc. - and a discursive approach based on 'minimal criteria' and inspired by the Essex School (Towshend 2003). It is true that the theoretical and methodological corpus of the Essex School has not been thus far adequately combined with quantitative measures of analysis. Thus, combining the Essex School conceptual toolkit with quantitative methods, and especially ones that are based on surveys, constitutes a timely priority as well as a considerable challenge. Obviously, our aim is not some kind of fusion of discourse theory with attitudes measurement, but rather the establishment of a constructive dialogue and exchange between the two traditions and methods. To be sure, methodological distance remains between discursive and survey approaches. There is, for example, a mounting critical bibliography on the use of attitudes in social (especially discursive) psychology that highlights the often ignored variability and instability of attitudes, as well as questioning the very applicability of the term/theory in discursive inquiry (see Schwarz and Bohner 2001; Potter and Wetherell 1987; Potter 1998; Ajzen 2005). Thus, from a discursive point of view the 'attitudes' captured and represented here are not regarded as underlying entities that algorithmically predetermine or generate specific behaviours, discursive patterns and public views (see also, in this respect, Potter \& Wetherell 1987: 43-55). They are rather interpreted as discursive units like many others, and thus not as privileged entry points into the real (and/or supposedly stable) identity or the behavioural predispositions of social subjects. In other words, by capturing certain attitudes among candidates at a certain point, we aim to offer an additional yet crucial glimpse of an aspect/element of the broader discursive articulations of populist and nonpopulist parties, which can be assessed side by side, 
for example, with the official discourse of these parties to be found in party documents and electoral manifestos. In this context, and despite the internal differentiations between attitudes, emerging or non-emerging patterns, convergence or divergence with other findings stemming from discursive or ideological/ideational approaches to populism, the exercise attempted here might tell us something useful about the very nature of populism itself and the best way to research it.

Now, the theorists that developed the Essex School approach (see Laclau 1977, 1980, 2005a, 2005b; Panizza 2005; Stavrakakis 2004; Stavrakakis and Katsambekis 2014; Katsambekis 2016) have indeed gradually constructed a distinct model of defining populism, one that has recently attracted the attention of mainstream theorists (Hawkins 2010: 10). This model is based on two minimal discursive criteria. In particular, it maintains that in order to qualify a movement or party as 'populist', the discursive practices associated with the agents under examination should:

a) stage a polarized representation of society as divided between two main blocs: i.e. the establishment, the power block versus the underdog (in opposition to consensual and/or technocratic discourses highlighting the continuity of the social fabric). b) involve claims to represent one of the poles implicated in this uneven dualist distribution, the one associated with the excluded/subordinated part, namely 'the people' (in some languages reference is made to a whole series of equivalent signifiers performing this representational operation; in Spanish, for example, the populism of PODEMOS refers to 'la gente' as well as to 'el pueblo', etc.).

According to this line of argument, both indications need to be present for a discourse or a movement to be classified as 'populist': a dichotomic view of the social field and 'the people' as a discursive nodal point. Otherwise no useful differential classification can emerge to the extent that far too many political discourses could be 
associated with only one of the two without, of course, being populist. Hence, on the one hand, these criteria can produce operational mappings of the political frontiers between populist and non-populist or anti-populist camps in particular contexts - as well as accounting for their occasional sedimentation through the emergence and establishment of a populist/anti-populist cleavage in certain political cultures (Pappas 2014: 58); on the other, they also register the vast plurality of different and often conflicting political articulations populist profiles can acquire.

Having registered the communication between the new mainstream and the Essex School, it should be clear that we employ a discursive perspective. Recent scholarship has highlighted the ambiguities, contradictions and impasses of the currently dominant 'ideological' or 'ideational' approach, mainly advocated by Cas Mudde (2007) (Aslanidis 2015). It is crucial to stress here that even scholars that claim to understand populism along the lines of Mudde's perspective, often avoid ascribing to populism the character of an ideology ('thin' or otherwise). An interesting example here is Stijn van Kessel, who departs from Mudde's remarks in order to offer a definition that stresses the discursive elements of populism (van Kessel 2015: 13), understanding it more as a 'set of ideas' (Kessel 2015: 11). In fact, van Kessel highlights right from the first page of his latest book that he aims to 'identify parties that stand out from the others in terms of their consistent expression of a populist discourse' (Kessel 2015: 1). To sum up, dropping the ideological clause means that we clearly acknowledge the lack of coherence and continuity in terms of values, policies, programmes, etc. between populist parties and movements. It means that we opt to shift the emphasis from content to form; that we choose to focus primarily on their shared logic, on the particular way in which the various discursive elements are organised and articulated in a given discourse. Such a choice is clearly 
reflected in the way our survey items are formulated. This, however, does not mean that we are throwing the baby out with the bathwater. Despite the shortcomings of the ideological/ideational approach to populism, we acknowledge that there is undisputable merit in the relevant theoretical corpus and empirical research as well some shared premises with discourse analysis. In this sense, our stance is not one of rejection, but rather of creative incorporation (see also Stavrakakis \& Katsambekis 2014: 122).

\section{Right-wing vs. left-wing populist profiles}

A second concern of contemporary discursive approaches (also see Stavrakakis and Katsambekis 2014), has to do with the varying contents of populist discourses and the different significations of the 'people' and the 'elite', or 'the people' and its 'other(s)'. For example, when studying the recent Greek experience one immediately realizes that the content of SYRIZA's discourse, regarding who the 'people' are, could not be furthest from the populist right and extreme-right rhetoric of other parties, which are often described as populist as well. What becomes thus visible is two very different conceptualizations of the 'people' circulating in the Greek public sphere: the first, put forward mainly by SYRIZA, seems to be active, pluralist, inclusive, democratic and emancipatory; the second, characteristic of extreme or extremist right-wing parties, is predominantly nationalist, rather passive, even racially and ethnically pure, antidemocratic and authoritarian (Stavrakakis and Katsambekis 2014: 135). For example, the Independent Greeks (ANEL), a populist and nationalist right-wing party (currently SYRIZA's government coalition partner), understand the people as the 'Greek people', as a predominantly national people. Moving to the (neo-nazi) extreme-right, one finds Golden Dawn, which also portrays 'the people' as a 'national people'; 
actually a racially pure and ethnic people, very close to a Greek version of Aryanism. At the same time, the enemy of the people is most often identified with persecuted minorities (immigrants, refugees, etc.). In this sense, and although Golden Dawn is sometimes referred to as a populist party (Anastasakis 2013; Halikiopoulou and Vasilopoulou 2013), it would be a huge category mistake to designate Golden Dawn, an extremist para-military organization/party with clear Nazi-like characteristics, as predominantly 'populist': any references to the 'people' within its discourse remains peripheral, ultimately reduced to a nativist and racist conception of the nation, which functions as the nodal point of its discursive articulation. Indeed, not only is 'people' reduced to 'nation' or 'race' in Golden Dawn rhetoric; at the same time (popular) representation is replaced by some sort of direct embodiment along the lines of the Führerprinzip.

Up to now, the above contradiction between left and right-wing articulations of populism has been conceptualized mainly with reference to different geographical regions. For example, Cas Mudde and Cristóbal Rovira Kaltwasser (2013) elaborate their distinction in geographical terms, with Latin America being recognized as the locus of left-wing inclusionary populism, while Europe is presented as the locus of right-wing exclusionary populism (also see Gidron and Bonikowski 2014: 5). Even though such geographical classifications might have held substantial truth-value up until a few years ago, it may be that today such schemas of exclusive geographical association need to be re-examined with emphasis placed on the socio-economic conditions (i.e. the role of economic and debt crises, political culture, etc.) and the political implications pertaining to each case. Such an emphasis might reveal similarities between Latin American and European countries that were not visible a few years ago. For example, we knew that left-wing populism existed in Europe all 
along (March 2011: 122). In the crisis context, however, certain left-wing populist forces have acquired significant electoral appeal in a variety of European countries (Greece, Spain, the Netherlands, etc.). It may, thus, make sense to bracket the geographical criterion, sticking to the socio-political and discursive one instead, and thus investigating the specificities of left-wing populism(s) versus the specificities of right-wing populism(s), that is to say negotiating the very boundary between the two, without a priori attributing them to particular historical or geographical contexts.

Moreover, the antithesis between right-wing and left-wing populisms, as represented by the divide 'inclusion versus exclusion' (Mudde and Kaltwasser 2013), but also marking the complex relationship between people and nation or demos and ethnos, should be examined within the scope of ideological/discursive frames and differentiations and their influence on political behaviour. For example, it has been recently argued that what actually shapes the behaviour of right-wing or left-wing populists in parliamentary politics is primarily their ideologico-political commitments, and not 'populism' per se. In an extensive comparative study of the parliamentary behaviour of the Dutch Socialist Party (SP) and the Party for Freedom (PVV), which stand as examples of left-wing and right-wing populist parties respectively, Simon Otjes and Tom Louwerse have shown that their parliamentary choices were dictated by their left-wing or right-wing ideology and not by their alleged 'populism' (Otjes and Louwerse 2013: 16). Thus, the PVV voted in a much more similar way to the mainstream centre-right VVD, while SP's behaviour was closer to the Labour Party (PvdA) and the Green Left. The most significant issue where these differences played out regarded - not surprisingly - policies on immigration (Otjes and Louwerse 2013: 15-16). Katsambekis $(2014,2015)$ has observed a similar pattern within the Greek political system, concerning especially SYRIZA and ANEL. Hence, while the two 
parties formed two coalition governments between January and September 2015, they clashed when SYRIZA proposed a law in June 2015 that would grant full citizenship rights to the majority of second generation immigrants and especially immigrant children. The bill was eventually voted down by ANEL, but passed with the support of parties of the liberal centre and the centre-left (RIVER [Potami], PASOK). The same happened with the new legal framework concerning same-sex civil unions passed by the Greek Parliament on 23 December 2015.

Now, the above research hypotheses and orientations have been mostly based on the qualitative analysis of discursive materials. By testing these findings through quantitative means, we purport to further consolidate certain theses on two levels: (a) regarding the distinctive character of populist and non-populist parties, and (b) regarding the sharp (?) difference between populist parties of the Left and the Right.

Hence, we are expecting to see, first, a central position attributed to 'the people' within the discourse/attitudes of parties designated as populist, while assuming that 'the people' would occupy a less significant position in non-populist ones; second, a strong antagonistic conception of society that represents the 'people' and the 'elites' as two rival camps in the first group; and third, a more inclusivist and pluralist conception of 'the people' on the left of the political spectrum, against a rather exclusivist and homogenizing one on the right (examining attitudes towards immigration and specific social groups, like homosexuals, etc., would be crucial here). Last but not least, affinities between parties regarding inclusivity/exclusivity and thus views on immigration should be more significant with regard to their positioning on the ideologico-political spectrum (Left-Right) and not with regard to their populist or non-populist profile (e.g. ANEL should be closer to ND, and SYRIZA should be closer to PASOK and RIVER). 


\section{Data}

The Greek Candidate Study is part of the Comparative Candidate Survey (CCS) which is a joint multi-national project with the goal of collecting data on candidates running for national parliamentary elections in different countries using a common core questionnaire in a post-election candidate survey conducted in each country. CCS is conducted after the elections in order to collect data at the same period that data on voters are collected as part of national election studies. This means that in order to understand the findings presented in the following sections of this paper, we should take into account that the candidates give their answer when they already know the electoral outcome and whether their political parties are in government or not.

It should be noted that, in theory, the target population of the CCS comprises all the candidates who have participated in the parliamentary election. In practice, when the members of each national research team organize the national candidate survey, they have to take into account the specific characteristics of their country. There are three significant factors that affect their decisions in this respect: (a) the funds available for a given survey (b) the relative size and importance of each political party within the national party system and (c) the availability of contact details of the candidates. The first two factors (funds and parties) interact with each other: if the funds are adequate, the survey can target the candidates of all parties. On the other hand, if funds are limited, only the candidates of the larger, more significant parties can be included in the designed sample. The third factor sometimes depends on the first factor; however, there are occasions in which the contact details of the candidates remain inaccessible even when funding is not an issue. In order to clarify 
this argument, let's imagine a situation in which we want to obtain a list of the email addresses of the candidates of a particular party. What happens if this party declines to provide this list? If the candidates of this party have their own personal websites or blogs it may be possible to collect the necessary information by visiting the corresponding websites and harvesting the email addresses. In this case the whole process would require some extra time and resources, but it would be possible to create the required list of email addresses. On the other hand, if the candidates of the party do not have personal websites or blogs, it may be impossible to collect the email addresses, or any other contact details, no matter what the level of available funds is. ${ }^{1}$ In Greece CCS is usually run as a mixed-mode survey and the first mode is always a web-survey (Andreadis 2010) with invitations and reminders sent to the email address of the candidates. The data of these studies are available from the website of the Hellenic National Election Studies (http://www.elnes.gr) and have been used in many national and international publications (e.g. Andreadis 2012; Freire et al 2014; Teperoglou, Chadjipadelis and Andreadis 2010; Teperoglou et al 2014).

The selection of the target population of the Greek CCS has been determined by the aforementioned set of three factors: funds, significance of parties and availability of contact details. Due to the limited resources of the Greek CCS research team, the target population cannot include all the candidates of the 22 parties and party coalitions that participated in the Greek parliamentary elections of January 2015. The target population has thus been limited to the candidates of the larger parties. In addition, the Communist Party of Greece (KKE) and Golden Dawn (GD) have always and consistently refused to provide a list of email addresses for their candidates. To make things worse, the candidates of these parties are usually selected directly by the party leadership. Most of them do not run personal campaigns, they do not have 
personal websites and it is arguably impossible to find their personal contact details. ${ }^{2}$ At the same time, obtaining a limited number of questionnaires from these parties makes impossible any reliable statistical processing. ${ }^{3}$ As a result, the Greek Candidate datasets could not include these parties.

At any rate, the lack of KKE and GD candidates is not anticipated to create substantial problems for our analysis. Firstly, because we never purported to argue that our populism index can examine and classify all 22 parties that participated in the elections. This would be extremely costly and probably useless, mainly because, for most of the smaller Greek parties, it is not known by other methods (such as discourse analysis) and has not been publicly debated whether they should be considered populist or not. Instead, what is really and crucially at stake is whether it is possible to identify and classify as populist (or not) the five parties that are included in the dataset; it is here that one can compare an overall consensus on their populist or nonpopulist profile - in fact, a consensus corroborated by a discursive methodology (Stavrakakis and Katsambekis 2014) - with the mapping resulting from the (innovative) use of our index in a candidate survey. Secondly, because as far as the populism/anti-populism axis is concerned, both KKE and Golden Dawn are marginal cases: although they both endorse an antagonistic confrontational discursive schema (fulfilling the first criterion of a discursive approach to populism), the role of the 'people' is only secondary in their discourse as it stands as a convenient synecdoche of an essentialized trans-historical notion of 'the working class' (KKE) and an ethnically and racially pure conception of the 'nation' (Golden Dawn). A thorough literature review indeed reveals that KKE is hardly ever discussed as a populist force (Papathanassopoulos, Giannouli, and Andreadis 2016); and as for the debating of Golden Dawn as populist, as we have already seen, it seems to be completely 
misplaced both from a discursive and an ideational perspective (Stavrakakis and Katsambekis 2014: 135; Mudde 2015).

For the Greek part of the study we have used 6 items that were included in the battery proposed to CSES plus 2 additional items elaborated from a discursive perspective. The only item that had to be changed because it was not suitable for candidates was the question: 'I would rather be represented by a citizen than by a specialized politician' that was changed to 'People can be better represented by a citizen than by a specialized politician'. A statement with this meaning is not expected by a mainstream politician, but there are many examples of populist leaders who have expressed similar ideas, arguing that they should not be seen as politicians (Panizza 2005: 21). Instead, they claim to be ordinary citizens and when they get in dialogue with the people they follow Berlusconi who used to adopt the phrase: "I am one of you" (Tarchi 2002: 133). This approach seems to work for Donald Trump as well, who gets endorsements for not being a 'professional' politician, but one of the people.

We have also avoided to include any item that refers to politics as a struggle between 'good' and 'evil'. Whenever a similar item was used in a survey it either has not loaded heavily in the factors (both US studies in Hawkins et al 2012) or it has loaded higher on the elitism dimension (Akkerman et al 2013). Trying to justify the failure of this item to load on the populism factor, Akkerman et al have argued that the item may have been interpreted more strictly along religious lines and that it may be more suitable for the 'Latin American context, where populist leaders use a more religiously inspired discourse' (ibid., 12). Thus, the items we have used clearly involve a polarized viewpoint of a society that is divided between two main blocs, but the moral dimension, i.e. the opposition of 'good' against 'evil' (which may be as 
well used by the supporters of the anti-populism camp in order to accuse populist actors) is not included in our items.

Indeed, from a discursive perspective as well, definitions of populism overstressing the importance of a moralistic signification of the antagonism between 'the people' and the 'elite', where the former is perceived as 'good', 'pure' and/or 'homogeneous' and the latter is regarded as 'corrupt' and 'evil' (Mudde 2007; see also Mudde and Kaltwasser 2012) need to be engaged with caution, bracketing the significance of moral investment and idealization as minimal criteria for the differential identification of populism. The reason for such bracketing is that attributions of purity and idealization - probably remnants of a religious imagery reemerging in secular form - can be encountered in a variety of discourses articulated around very different nodal points. De la Torre is right to point out that such narratives of redemption epitomize 'the saga of the people, the proletariat, the indigenous, or the nation' (De la Torre 2015: 10). Interestingly enough, today the 'markets' are also routinely invested with such imagery of purity to the extent that market sovereignty increasingly replaces popular sovereignty as the overarching legitimizing mechanism of austerity policies in Europe and beyond. No wonder that for many influential critical political theorists the turn to moralistic discourse, 'the displacement of politics by morality', constitutes a defining characteristic of antipopulist consensual politics positioned beyond left and right; here moral condemnation is revealed as a neoliberal strategy of exorcizing the populist challenge (Mouffe 2002: 1, 14). If this is indeed the case then this criterion may be more useful in determining the degree, the depth and salience, of a given populist (or other) identification. At any rate, we are not arguing that moralistic arguments are not present in populist discourses. They may as well be present, as they are in most types 
of political discourse, animating different types of antagonistic divides. What we are rather suggesting is that a moralistic logic/rationale is not characteristic exclusively of populism, and thus cannot form part of its minimal definition. Moreover, there have been studies that illustrate that a populist discourse might operate without overly relying on moralistic rhetoric (e.g. Stavrakakis \& Katsambekis 2014; Katsambekis 2016).

All in all, in our analysis, one item (the one concerning the moral dimension) is excluded and two new ones are added, marking in this way a first shift/variation with regard to 'mainstream' approaches. To be sure, we acknowledge that there is much more to be done in the direction of adjusting quantitative research toward a more discourse-oriented perspective in the analysis of the populist phenomenon. This is why we have opted to understand this paper as a 'pilot study.'

The battery of the eight items was thus formulated as follows and they were included as 5-point Likert items using the following coding 1: Strongly disagree, 2: Disagree, 3: Neither agree nor disagree, 4: Agree, 5: Strongly agree:

POP1. The politicians in parliament need to follow the will of the people.

POP2. The people, and not politicians, should make our most important policy decisions.

POP3. The political differences between the elite and the people are larger than the differences among the people.

POP4. People can be better represented by a citizen than by a specialized politician. POP5. Elected officials talk too much and take too little action. POP6. What people call 'compromise' in politics is really just selling out on one's principles. 
POP7. Popular demands are today ignored in favour of what benefits the establishment.

POP8. Political forces representing the people should adopt a more confrontational attitude in order to make their voice heard and influence decision-making.

The two new items (POP7 and POP8) were added in a bid to capture the nature and the depth of the perceived antagonistic divide between people and establishment/elite (previously only covered by POP3 to the extent that in most other items it is the relationship between people and politicians that is at stake). In particular, a high score in POP7 would reflect a sharp contrast between the perceived interests of 'the people' and the interests of the 'establishment', while a lower score would mean that a representation of society in such antagonistic terms is not prevalent. With POP8 we aim at further investigating and clarifying the linkage between populist discourses/attitudes and sharp antagonistic political logics as well as that between non-populist discourses/attitudes and 'institutional', non-confrontational ones. A high score in this case would thus reflect a more confrontational political rationale, close to what Laclau has described as the 'logic of equivalence', while a low score would reflect what we can describe as a more 'institutional' political rationale, close to what Laclau has described as the 'logic of difference' (Laclau 2005a: 77-78; Laclau 2005b: 37).

\section{Findings}

The Greek CCS 2015 was conducted from mid-February to end of July 2015 as a web survey. The population of interest is the group of all candidates running with the five following parties: SYRIZA, ND, RIVER, PASOK, ANEL. Andreadis (2016) 
estimates the response rate of the Greek CCS 2015 between $35.2 \%$ and $37.6 \%$

(depending on how the cases of unknown eligibility are used in the formula). Since the targeted population includes the same number of candidates from each of the five parties, in a representative sample each party should be represented by circa $20 \%$. The distribution of completed questionnaires per party is presented in Table 1 demonstrating that the distribution per party in the sample is similar to the distribution per party in the population.

$<$ Table 1 around here $>>$

According to Andreadis (2016): (a) the distribution of the candidates in the sample is very similar to the corresponding distribution in the population with regard to their electoral districts, (b) the elected MPs are slightly under-represented in the sample, but the gap is not very large ( $8.1 \%$ of the sample and $12.5 \%$ of the population $)^{4}$ and (c) there is a high level of correspondence between sample and population as far as gender distribution is concerned.

In Table 2 we present the descriptive statistics for the eight populist attitudes items that were included in the Greek CCS 2015. The table shows the number of responses $(\mathrm{N})$ for each variable, its mean value, standard deviation and median. The median is included in the table as a more appropriate measure of central tendency because the variables are ordinal. The mean value for two of the items (POP4 and POP6) is less than 3 (i.e. the middle category of the scale). In fact, the median of POP 6 is 2 , indicating that half of the candidates disagree with the idea that compromising is equal to selling out. The highest mean value is observed for item POP8: 'Political 
forces representing the people should adopt a more confrontational attitude in order to make their voice heard and influence decision-making'.

$$
<<\text { Table } 2 \text { around here }>>
$$

In the Appendix we test the reliability and unidimensionality of the scale. The reliability is tested with both Cronbach's alpha and ordinal alpha (Gadermann, Guhn and Zumbo, 2012). The unidimensionality is tested with factor analysis and Mokken scale analysis (van Schuur, 2003; Germann and Mendez, 2015) using the R package mokken (Van der Ark, 2012). All the tests we have used indicate that excluding POP5 gives a better scale. Thus, we have dropped this item and our populism index is constructed as the mean value of the remaining seven populist attitude items. ${ }^{5}$ As Figure 1 indicates, according to the populism index the candidates of PASOK, ND and RIVER - parties generally assumed to be non-populist, something also consistent with our discursive framework - score below 3.5 while the candidates of both SYRIZA and ANEL - parties generally assumed to be populist, something also consistent with our discursive framework - score over 3.5. As their $95 \%$ confidence intervals indicate, ANEL candidates score higher than SYRIZA candidates on the populism index. PASOK, ND and RIVER candidates do not differ significantly on the same index and they form a common group. But this group (the candidates of PASOK, ND and RIVER) scores significantly lower on this scale and it is significantly different from the groups of SYRIZA and ANEL candidates. 
Greece is not only one of the few countries with both significant left-wing and rightwing populist parties. In addition, it currently has a coalition government formed by a left-wing and a right-wing populist party. This allows for very interesting comparisons of left-wing and right-wing populist candidates. In order to study if there are differences between the (assumed) left-wing populism of SYRIZA candidates and the (assumed) right-wing populism of ANEL candidates we have run a t-test for each of the items to compare between the candidates of these parties.

As Table 3 indicates, the significance value $\mathrm{p}$ of the mean comparison between the candidates of SYRIZA and ANEL is less than 0.05 for six out of the seven items included in the scale. The item with the largest difference between SYRIZA and ANEL candidates is the item: 'What people call compromise in politics is really just selling out on one's principles'. In this respect, SYRIZA candidates' score is 2.84 and ANEL candidates' score is 3.59. The p value of the t-test is less than 0.001. This finding is consistent with Akkerman, Mudde and Zaslove (2013) who find a similar distinction between left-wing and right-wing populism. In particular, they have observed that the voters of the left-wing SP are more willing to listen to the opinions of others and they argue that this finding is consistent with the idea that right-wing populism is exclusionist, while left-wing populism is more inclusivist. Another - supplementary - explanation here is that the differing views on 'compromise' stem from different political cultures that have developed in different circumstances and along different time-spans. SYRIZA's officials have a longer history within party politics and other forms of representative institutions (like trade unions) within a larger and more coherently organized structure (around $80 \%$ of SYRIZA's cadres come from Synaspismos, which was founded in 1992, while a lot of them also originate from the Greek Communist Party / KKE). On the other hand, 
ANEL constitute a considerably leader-centric party that was practically built around the persona of their leader, Panos Kammenos, a former ND MP, from 2012 onwards. Its cadres have not thus developed the type of militancy and institutional culture that the cadres of SYRIZA have built within their party.

\section{$<<$ Table 3 around here $>$}

In order to further explore the differences between right-wing and left-wing populism on the supply side in Greece we have used items reflecting socio-cultural issues from the Greek Voting Advice Application HelpMeVote 2015 (Andreadis 2015). These items (available at: http://doi.org/10.3886/E26659V15) were included in the questionnaire of the Greek Candidate Study 2015 and provide significant data on the different attitudes along the GAL (Green, Alternative, Libertarian) vs TAN (Traditional, Authoritarian, Nationalist) dimension (Hooghe, Marks, and Wilson 2002). In the index produced along these lines larger values appear for the candidates who promote the ideas of security and national identity, the exclusion of immigrants and other groups such as homosexuals. Candidates with lower scores are those who support pro-immigrant policies and promote personal freedom rights.

\section{$<<$ Table 4 around here $>>$}

Table 4 shows that there is a chasm separating SYRIZA and ANEL with regard to their attitudes toward issues such as crime and immigration. The scores of SYRIZA and ANEL candidates on the Green-Alternative-Libertarian (GAL) vs TraditionalAuthoritarian-Nationalist (TAN) index are 1.9 and 3.4 respectively, providing 
additional support to the hypothesis that right-wing populism is exclusionary and identity-focused, while left-wing populism is more inclusionary and pluralist.

For a more detailed presentation of the differences between candidates of leftwing and right-wing populist parties we can refer to Table 5 that presents the distribution of answers per party on immigration. Indeed this table shows a significant difference between candidates of left-wing and right-wing populist parties. The majority of ANEL candidates (58.3\%) support that immigrants who come to Greece should be required to adopt Greek customs. On the other hand, the majority of SYRIZA candidates $(68.5 \%)$ disagree with this idea. It is interesting that the two populist parties occupy the extreme positions and they are clearly separated by the mainstream parties, which are located in the middle. What is also very clear in this table is that candidate attitudes regarding this issue are strictly determined by their ideological/political commitment in terms of a socio-cultural Right/Left polarity, since they are distributed along a perfect sequence from the (radical) right to the (radical) left.

$<<$ Table 5 around here $>>$

\section{Conclusion}

In this paper we have used candidate responses on a re-formulated battery of populist items creating an index of populist attitudes for each respondent. We have demonstrated that this index can be used to discriminate between populist and nonpopulist parties in contemporary Greece. More specifically, our findings show that the candidates of the parties that have been generally categorized as populist and also 
qualify as such using discourse analysis (in dialogue with the 'new mainstream' in populism studies), namely SYRIZA and ANEL, score significantly higher than the candidates of the mainstream parties, usually designated as non-populist or antipopulist.

Our second task was to investigate if we can use these and additional survey items to discriminate between left-wing and right-wing populism. Using the candidate data we have found that the candidates of the left-wing populist party SYRIZA are more willing to listen to other opinions and to compromise than the candidates of the right-wing populist party ANEL. Using additional survey items we have concluded that right-wing populism is exclusionary and identity-focused, while left-wing populism is more inclusive and pluralist. Indeed inclusionary and pluralist attitudes are stronger on the left of the political spectrum than on the right, and thus affinities are bigger with regard to positioning on the ideologico-political spectrum (Left-Right) and not with regard to a populist or non-populist profile (e.g. ANEL appear closer to the mainstream right or centre-right ND, and SYRIZA closer to the centre or centreleft, PASOK and RIVER). The findings in Table 5 regarding attitudes towards immigration merely confirm that regarding specific policy areas, as in parliamentary behaviour (Otjes and Louwerse 2013), left-wing or right-wing commitments seem to be much more important in shaping attitudes and/or behaviour, than populism per se.

To sum up, what this pilot study shows is that there is indeed open ground for the mutual cross-fertilization of qualitative discursive methods and quantitative techniques like surveys in the study of populism. Based on a definition that understands populism through the isolation of 'minimal criteria' we were able to formulate corresponding questions to test our hypotheses, enriching and re-focusing mainstream orientations. What is more, our findings have revealed differences among 
populist parties that were not evident through qualitative discourse analysis, namely the willingness of SYRIZA's candidates to accept compromise more easily than the ones of ANEL. On this level, we should go back to our qualitative data and inquire under this new light for evidence of such signals in public discourse materials. This also means that surveys do not merely test hypotheses already formulated within a theoretical/qualitative context. They also generate feedback that can lead to further investigations on the discursive level, adding an important reflexive element in our research strategy. At the same time, the utilization of discourse theory in this study has been rather cautious, limited to the re-formulation of the battery (by theoretically supporting the exclusion of a certain item and by contributing two new items). Such 'experiments' need to be conducted very carefully in order to allow meaningful communication between scholars working with different traditions. Future research could explore the possibility of developing more substantive links on this front extending much further the scope of methodological cross-fertilization.

It should have become clear up to this point that the candidate survey establishes a clear, indeed a sharp distinction between populist and non-populist parties within the Greek political system. This means that on the supply-side one indeed finds evidence that supports the different categorization of certain parties within the political system along the lines of our theoretical framework. Now, it remains to be seen if such populist or non-populist outlooks match the demand-side; in other words, do these candidates/politicians represent actually existing demands and attitudes that are expressed from their voter constituency, leading to the creation of sustainable bonds between the two sides? Now, one might argue here that this is a false distinction/dilemma, since public opinion and communication in totto is constructed at the level of discourse, as political actors actively shape the (collective) 
identities of the social subjects to which they appeal and vice-versa. However, the distinction we actually have in mind is one consistent with post-Althusserian discourse theory as it differentiates between interpellation, the transmission of a (populist) message/call from above, which simultaneously creates its subjects, and identification, the reception of a (populist) message from below in terms of subjective investment and active self-placement within a discursive structure (Jorgensen \& Phillips 2002: 15, 40-1, 43). Such a distinction may be utilized as a qualification of the classic supply and demand opposition.

Of course, the empirical analysis conducted in this paper is Greece-specific, hence the wider validity of the index we have developed will require its future application in other contexts. In this respect, it is in our immediate plans to proceed with such a research that will shed additional light to the hypotheses and findings presented here. It also remains to be seen whether our method is suitable to research other countries in the European context and beyond; it seems, however, plausible to expect that similar results will be generated in countries facing similar challenges in crisis-ridden Europe and exhibiting a similar political culture. After all, certain items of the questionnaire we have utilised have already been used in other contexts (as has been illustrated in our literature review above).

Regarding further future research, our attempt here is indicative of the merits of adopting a multiple-methods strategy in researching, understanding and 'measuring' populism on the levels of discourse and voters'/candidates' attitudes. Additional methods that could be adopted here, in order to arrive at an even wider scope of inquiry/justification include computer assisted discourse analysis and indepth analysis of patterns of parliamentary behaviour. Additional subjects of study would, in the first instance, encompass congruence between candidates and voters in 
the Greek context and beyond. Our discursive methodology provides the concrete basis for a strategy that could simultaneously utilize different research approaches and can serve both as the source for the formulation of questions/hypotheses on each level and as a reflexive tool for the analysis of the respective research outcomes.

\section{Notes}

1. For some readers it may be surprising that certain parties refuse to participate in an academic research project, but this depends on the country under study. According to Trechsel and Mair (2011) the pan-European Voting Advice Application euprofiler has asked European political parties to code themselves. The overall response rate was $37.6 \%$ but its variability per country was enormous. For countries with long tradition of co-operation between parties and VAA designers (e.g. Belgium, Finland, the Netherlands) the response rate was larger than $75 \%$, but in Greece only 3 out of 7 parties contacted have responded (42.9\% response rate).

2. The interested reader can easily verify that most of the elected MPs of KKE cannot be contacted directly via email. A simple visit to the website of the Greek Parliament: http://www.hellenicparliament.gr shows that almost all KKE MPs either do not have an email account or they have a common email account that belongs to the party:

\section{kke@parliament.gr}

3. The Greek Candidate Study 2015 includes only one completed questionnaire from KKE and five completed questionnaires from Golden Dawn candidates.

4. At this point it should also be noted that we have replicated the analysis of the following sections in the sub-group of the sample that is created after the removal of the elected MPs, and we have received similar results. When we examine only the 
non-elected MPs, all parties appear slightly more populist, but the difference of the populism index is less than $0.5 \%$ for all other parties and less than $1.5 \%$ for SYRIZA, the party with the larger number of MPs. We note that if elected MPs are removed, the group of SYRIZA candidates will be the smaller in the sample, because this party has the smaller number of non-elected candidates (e.g. SYRIZA: out of 412 candidates, 144 have been elected, ND: out of 412 candidates, 72 have been elected, etc). In order to have almost the same number of candidates per party we opted to keep both elected and non-elected MPs in the sample.

5. As an additional test, we have built a second populism index as the mean of all eight items. Replicating the analysis with this index we get very similar results.

\section{References}

Ajzen I. (2005) Attitudes, personality and behavior (second edition), Berkshire: Open University Press.

Akkerman A., Mudde C. and Zaslove A. (2013) 'How populist are the people? Measuring populist attitudes in voters', Comparative Political Studies, DOI: 10.1177/0010414013512600.

Anastasakis O. (2013) 'Greece's Radical Politics in the Dark Side of the Dawn', http://www.e-ir.info/2013/11/05/greeces-radical-politics-on-the-dark-side-ofdawn/

Andreadis I. (2010) 'Web-based Political Surveys' (Greek). Proceedings of the 23rd Panhellenic Statistics Conference: 'Statistics and Internet'. Veroia, 7-11 April 2010, available online at: http://invenio.lib.auth.gr/record/126916/files/Webbased-surveys.pdf 
Andreadis I. (2012) 'Measuring satisfaction with democracy among candidates: What is the effect of the electoral outcome?', paper presented at the 2nd Plenary Conference of the CCS, MZES, University of Mannheim, 27-29 January 2012. Andreadis I. (2013) 'Voting Advice Applications: a successful nexus between informatics and political science'. BCI '13, September 19 - 21 2013, Thessaloniki, Greece http://doi.acm.org/10.1145/2490257.2490263

Andreadis I. (2015) 'The Greek Voter according to HelpMeVote 2015 users', http://www.polres.gr/en/sites/default/files/The-Greek-Voter.pdf

Andreadis I. (2016) 'The Greek Candidate Study 2015', Ann Arbor, MI: Interuniversity Consortium for Political and Social Research http://doi.org/10.3886/E62191V1

Aslanidis, P. (2015) 'Is Populism an Ideology? A Refutation and a New Perspective,' Political Studies (early view), DOI: 10.1111/1467-9248.12224.

De la Torre C. (2015) 'Introduction: Power to the People?', in De 1 Torre, C. (ed.) The Promise and Perils of Populism: Global Perspectives, Lexington: University Press of Kentucky.

De la Torre C. (ed.) The Promise and Perils of Populism: Global Perspectives, Lexington: University Press of Kentucky.

Freire A., Lisi M., Andreadis I. and Leite Viegas JM (2014) 'Political representation in bailed-out Southern Europe: Greece and Portugal compared'. South European Society and Politics, 19(4), 1-21.

Gadermann, A. M., Guhn, M., and Zumbo, B. D. (2012) 'Estimating ordinal reliability for Likert-type and ordinal item response data: A conceptual, empirical, and practical guide'. Practical Assessment, Research and Evaluation, 17(3), 1-13. 
Germann, M., and Mendez, F. (2015). 'Dynamic scale validation reloaded'. Quality and Quantity, DOI: 10.1007/s11135-015-0186-0.

Gidron N. and Bonikowski B. (2014) 'Varieties of Populism: Literature Review and Research Agenda', Working Paper Series, No. 13-0004, Weatherhead Center For International Affairs, Harvard University, http://scholar.harvard.edu/files/gidron_bonikowski_populismlitreview_2013.p $\underline{\text { df }}$

Halikiopoulou D. and Vasilopoulou S. (2013) 'The Rise of the Golden Dawn', in Giusto, H., Kitching, D. and Rizzo, S. (eds) The Changing Faces of Populism, Lexington Books, 107-124.

Hawkins KA (2010) Venezuela's Chavismo and Populism in Comparative Perspective, Cambridge: Cambridge University Press.

Hawkins KA, Riding S. and Mudde C. (2012) 'Measuring populist attitudes', Political Concepts Committee on Concepts and Methods, Working Paper Series.

Hawkins KA and Riding S. (2010) 'Populist Attitudes and their Correlates among Citizens: Survey Evidence from the Americas', Prepared for the ECPR Workshop 'Disassembling Populism (and Putting It Back Together Again): Collaborative Empirical Research on Interactions among Populism's Attributes', March 22-25, Muenster, Germany.

Hooghe L., Marks G. and Wilson CJ (2002) 'Does left/right structure party positions on European integration?', Comparative Political Studies, 35(8), 965-989.

Jagers J. and Walgrave S. (2007) 'Populism as political communication style: An empirical study of political parties' discourse in Belgium', European Journal of Political Research, 46(3), 319-345. 
Katsambekis G. (2014) 'Comparing right-wing and left-wing Populism(s)', Paper presented at the POPULISMUS international methodological workshop on Analyzing Populist Discourse, 11-13 July, Thessaloniki, https://www.academia.edu/7795292/Comparing_right-wing_and_leftwing_Populism_s

Katsambekis G. (2015) 'Left-wing and Right-wing populisms. A comparison of SYRIZA and the Independent Greeks (ANEL) in contemporary Greece', Paper presented at the PSA 65th Annual International Conference, 30 March 1 April, Sheffield.

Katsambekis G. (2016) 'Radical Left Populism in Contemporary Greece: Syriza's Trajectory from Minoritarian Opposition to Power,' Constellations, 23(3), 391-403.

Laclau E. (1977) Politics and Ideology in Marxist Theory: Capitalism, Fascism, Populism, London: New Left Books.

Laclau E. (1980) 'Populist Rupture and Discourse', Screen Education, 34, 87-93.

Laclau E. (2005a) The Populist Reason, London: Verso.

Laclau E. (2005b) 'Populism: What's in a Name?', in F. Panizza (ed.) Populism and the Mirror of Democracy, London: Verso, 32-49.

Mouffe C. (2002) Politics and Passions: The Stakes for Democracy, London: CSD.

Mudde C. (2007) Populist Radical Right Parties in Europe, Cambridge: Cambridge University Press.

Mudde C. (2015) 'Populism and liberal democracy: is Greece the exception or the future of Europe?', discussion with Antonis Galanopoulos, https://www.opendemocracy.net/can-europe-make-it/antonis- 
galanopoulos/interview-with-cas-mudde-populism-and-liberal-democracy-isgreece-exception-or-

Mudde C. and Rovira Kaltwasser C. (2012) 'Populism and (liberal) democracy: A framework for analysis', in Mudde, C. and Rovira Kaltwasser, C. (eds) Populism in Europe and the Americas: Threat or Corrective for Democracy?, Cambridge: Cambridge University Press.

Mudde C. and Rovira Kaltwasser C. (2013) 'Exclusionary vs. Inclusionary Populism: Comparing Contemporary Europe and Latin America', Government and Opposition, 48(2), 147-174.

Otjes S. and Louwerse T. (2013) 'Populists in Parliament: Comparing Left-Wing and Right-Wing Populism in the Netherlands', Political Studies, DOI: $10.1111 / 1467-9248.12089$.

Papathanassopoulos, S., Giannouli, I., and Andreadis, I. (2016) 'Greece: populism between left and right', in T. Aalberg, F. Esser, C. Reinemann, J. Stromback, C. De Vreese (Eds) Populist Political Communication in Europe, Routledge.

Pappas, T. S. (2014) Populism and crisis politics in Greece, Palgrave Macmillan.

Pauwels, T. (2011) 'Measuring populism: A quantitative text analysis of party literature in Belgium', Journal of Elections, Public Opinion and Parties, 21(1), 97-119.

Panizza, F. (Ed.). (2005) Populism and the Mirror of Democracy, London: Verso.

Potter J. (1998) 'Discursive Social Psychology: From Attitudes to Evaluative Practices'. European Review of Social Psychology, 9(1), 233-266.

Rooduijn, M., de Lange, S. L., and Van Der Brug, W. (2014) 'A populist Zeitgeist? Programmatic contagion by populist parties in Western Europe'. Party Politics, 20(4), 563-575. 
Rooduijn, M. and Pauwels, T. (2011) 'Measuring Populism: Comparing Two Methods of Content Analysis'. West European Politics, 34(6), 1272-1283. Schwarz N. and Bohner G. (2001) 'The Construction of Attitudes', in A. Tesser and N. Schwarz (eds.), Intrapersonal Processes, Oxford: Blackwell, 436-457.

Spruyt, B., Keppens, G. and Van Droogenbroeck, P. (2016) 'Who Supports Populism and What Attracts People to It?'. Political Research Quarterly, DOI: $10.1177 / 1065912916639138$.

Stavrakakis Y. (2004) 'Antinomies of Formalism: Laclau's Theory of Populism and the Lessons from Religious Populism in Greece', Journal of Political Ideologies, 9(3), 253-267.

Stavrakakis Y. (2013) 'The European Populist Challenge', Annals of the Croatian Political Science Association, 10(1), 25-39.

Stavrakakis Y. (2014) 'The Return of “the People”: Populism and Anti-Populism in the Shadow of the European Crisis', Constellations, 21(4), 505-517.

Stavrakakis Y. and Katsambekis G. (2014) 'Left-wing Populism in the European Periphery: The Case of SYRIZA', Journal of Political Ideologies, 19(2), 119142.

Tarchi, M. (2002) Populism Italian Style, in Y. Meny and Y. Surel (eds) Democracies and the Populist Challenge, Hampshire: Palgrave Macmillan, 120-138.

Teperoglou E., Chadjipadelis T. and Andreadis I. (2010) 'Cleavages of Voters and Candidates in the National and the European Dimension: Convergences and Divergences' (Greek), Science and Society - Journal of Political and Moral Theory, 25, 37-63. 
Teperoglou E., Freire A., Andreadis I. and Viegas JML (2014) 'Elites' and Voters' attitudes towards austerity policies and their consequences in Greece and Portugal', South European Society and Politics, 19(4), 457-476.

Townshend J. (2003) 'Discourse theory and political analysis: a new paradigm from the Essex School?', British Journal of Politics and International Relations, 5(1), 129-142.

Trechsel, A. H., and Mair, P. (2011). ,When parties (also) position themselves: An introduction to the EU Profiler', Journal of Information Technology and Politics, 8(1), 1-20.

Van der Ark, L. A. (2012) 'New developments in Mokken scale analysis in R', Journal of Statistical Software, 48(5), 1-27.

Van Kessel, S. (2015) Populist Parties in Europe, Hampshire: Palgrave Macmillan. Van Schuur, W. H. (2003) 'Mokken scale analysis: between the Guttman scale and parametric item response theory', Political Analysis, 11(2), 139-163.

(8872 words including endnotes and references but without the Appendix; the Appendix includes 966 words) 


\section{Appendix}

We need to test the internal consistency of the items mainly for two reasons. The first reason is that there are two new items that have not been tested before. The second reason is that the remaining six items have only been tested on voters so far. This is the first time these items are used on candidates, thus we need to check if the reliability of the scale remains intact when the scale is applied on candidates. Cronbach's alpha for the eight items included in the Greek Candidate Study gets the value of 0.80 , suggesting that the eight items have relatively high internal consistency. The item with the lower correlation (0.304) with the whole set of items is the item POP5 'Elected officials talk too much and take too little action'. If POP5 is removed, Cronbach's alpha for the remaining seven items becomes 0.81 . Since we have measurements involving ordinal data, we also calculate ordinal alpha. Ordinal alpha for the eight items is 0.83 and if POP5 is removed, it becomes 0.84 .

In order to test if the items form a unidimensional scale we can use factor analysis. If all items load on a single factor, then the scale is unidimensional. The first column of Table A.1 gives the output of a factor analysis using all the populist attitudes items. The loading of POP5 on the first factor (i.e. the correlation between POP5 and the latent variable of populist attitudes) is low (0.29). The second column gives the output of a factor analysis after excluding POP5. All factor loadings in the second column are rather high. In addition, the indexes of model fit presented at the bottom of the first two columns indicate that the second model is much better, as it becomes obvious by the smaller BIC in the second column. In addition, we observe that two of the three presented fit indexes of the first model are far from the thresholds 
used for accepted models, while the fit indexes of the second model are either within or very close to the range of suggested values of a good fit. For the root mean square error of approximation (RMSEA), the suggested cut-off value is between 0.06 and 0.07. For the non-normed fit index (NNFI) the suggested cut-off is 0.95 . Finally, for the standardized root mean square residual (SRMR), a value of .08 or less is indicative of an acceptable model. Following the suggestion by an anonymous reviewer to specify error correlations between consecutive items, we have applied Confirmatory Factor Analysis on the seven populist attitudes items and after consulting the modification indices we have been able to improve the fit indices: For instance, after specifying an error correlation between items POP7 and POP8, RMSEA decreases to 0.036 . This finding reinforces our argument that the model with the seven items is a good fit for our data.

Table A.1. Output of Factor and Mokken Scale Analysis

\begin{tabular}{|l|c|c|c|c|}
\hline & 8 items & 7 items & 8 items & 7 items \\
\hline & \multicolumn{5}{|c|}{ Factor loadings } & \multicolumn{2}{c|}{\begin{tabular}{c} 
Hi \\
\hline
\end{tabular}} \\
\hline POP1 & 0.667 & 0.682 & 0.415 & 0.462 \\
\hline POP2 & 0.683 & 0.701 & 0.422 & 0.467 \\
\hline POP3 & 0.557 & 0.565 & 0.352 & 0.383 \\
\hline POP4 & 0.493 & 0.481 & 0.347 & 0.345 \\
\hline POP5 & 0.293 & & 0.233 & \\
\hline POP6 & 0.709 & 0.695 & 0.464 & 0.479 \\
\hline POP7 & 0.624 & 0.608 & 0.399 & 0.406 \\
\hline POP8 & 0.578 & 0.574 & 0.389 & 0.412 \\
\hline \multicolumn{5}{|c|}{ Model fit } \\
\hline RMSEA & 0.095 & 0.07 & & \\
\hline NNFI & 0.871 & 0.944 & & \\
\hline RMSR & 0.06 & 0.04 & & \\
\hline BIC & -11.37 & -38.74 & & \\
\hline H & & & 0.381 & 0.422 \\
\hline \multicolumn{7}{|l|}{} & & \\
\hline
\end{tabular}


For ordinal items with different distribution it is better to use Mokken scale analysis instead of factor analysis. Thus, in order to verify the results provided by factor analysis, we have included in the last two columns of Table A.1 the output of Mokken scale analysis. In the third column we present the item scalability coefficients Hi. As a rule of thumb, in order to accept a set of items as a Mokken scale, the scalability coefficient for each item should be larger than 0.30 and POP5 fails this criterion. In the last column of the table we present the output of Mokken scale analysis on the remaining seven items. Now, all coefficients pass the 0.3 threshold. The scalability (homogeneity) coefficient $\mathrm{H}$ for the entire scale is improved from 0.381 (in the model with all eight items) to 0.422 (after excluding POP5). 
Table 1. Number of candidates per party in the sample

\begin{tabular}{|l|c|c|}
\hline Party & Frequency & Percent \\
\hline SYRIZA & 112 & 21.5 \\
\hline ND & 102 & 19.6 \\
\hline RIVER & 108 & 20.8 \\
\hline PASOK & 96 & 18.5 \\
\hline ANEL & 102 & 19.6 \\
\hline Total & 520 & 100.0 \\
\hline
\end{tabular}


Table 2. Descriptive statistics of the populist attitudes items

\begin{tabular}{|l|c|c|c|c|}
\hline & $\mathrm{N}$ & Mean & $\begin{array}{c}\text { Standard } \\
\text { Deviation }\end{array}$ & Median \\
\hline POP1 & 497 & 3.85 & 0.95 & 4 \\
\hline POP2 & 494 & 3.25 & 1.17 & 3 \\
\hline POP3 & 471 & 3.49 & 1.07 & 4 \\
\hline POP4 & 501 & 2.89 & 1.04 & 3 \\
\hline POP5 & 490 & 3.74 & 0.92 & 4 \\
\hline POP6 & 492 & 2.68 & 1.15 & 2 \\
\hline POP7 & 492 & 3.37 & 1.17 & 4 \\
\hline POP8 & 492 & 3.95 & 0.92 & 4 \\
\hline
\end{tabular}


Table 3. SYRIZA/ANEL differences per item

\begin{tabular}{|l|c|c|c|c|c|c|c|c|}
\hline & \multicolumn{3}{|c|}{ SYRIZA } & \multicolumn{3}{c|}{ ANEL } & & \\
\hline Item & $\mathrm{N}$ & Mean & S.D. & $\mathrm{N}$ & Mean & S.D. & $\mathrm{t}$ & $\mathrm{p}$ \\
\hline POP1 & 107 & 4.18 & 0.63 & 98 & 4.40 & 0.65 & -2.46 & 0.015 \\
\hline POP2 & 106 & 3.95 & 0.83 & 98 & 3.91 & 1.04 & 0.34 & 0.736 \\
\hline POP3 & 106 & 4.08 & 0.82 & 90 & 3.90 & 0.91 & 1.41 & 0.159 \\
\hline POP4 & 109 & 3.08 & 0.86 & 98 & 3.38 & 1.09 & -2.14 & 0.033 \\
\hline POP6 & 102 & 2.84 & 1.00 & 98 & 3.59 & 1.07 & -5.10 & $<0.001$ \\
\hline POP7 & 102 & 3.70 & 1.12 & 98 & 4.17 & 0.94 & -3.26 & 0.001 \\
\hline POP8 & 108 & 4.24 & 0.73 & 97 & 4.48 & 0.61 & -2.56 & 0.011 \\
\hline
\end{tabular}


Table 4. Comparison of Populism and TAN indexes per political party

\begin{tabular}{|l|l|c|c|c|c|c|}
\hline \multicolumn{2}{|c|}{} & SYRIZA & ND & RIVER & PASOK & ANEL \\
\hline \multirow{3}{*}{ Populism } & Mean & 3.73 & 2.99 & 3.03 & 2.97 & 3.98 \\
\cline { 2 - 7 } & Std. Deviation & 0.52 & 0.64 & 0.63 & 0.70 & 0.54 \\
\hline \multirow{2}{*}{ TAN } & Mean & 1.90 & 3.31 & 2.48 & 2.74 & 3.40 \\
\cline { 2 - 7 } & Std. Deviation & 0.45 & 0.44 & 0.44 & 0.56 & 0.49 \\
\hline
\end{tabular}


Table 5. 'Immigrants who come to Greece should be required to adopt Greek customs'; responses by political party

\begin{tabular}{|l|c|c|c|}
\hline Party & Disagree & $\begin{array}{l}\text { Neither } \\
\ldots \text { nor }\end{array}$ & Agree \\
\hline SYRIZA & $68.5 \%$ & $21.3 \%$ & $10.2 \%$ \\
\hline ND & $32.6 \%$ & $30.5 \%$ & $36.8 \%$ \\
\hline RIVER & $47.6 \%$ & $29.5 \%$ & $22.9 \%$ \\
\hline PASOK & $47.8 \%$ & $22.2 \%$ & $30.0 \%$ \\
\hline ANEL & $21.9 \%$ & $19.8 \%$ & $58.3 \%$ \\
\hline Total & $44.3 \%$ & $24.7 \%$ & $31.0 \%$ \\
\hline
\end{tabular}


Figure 1. Populism Index by political party

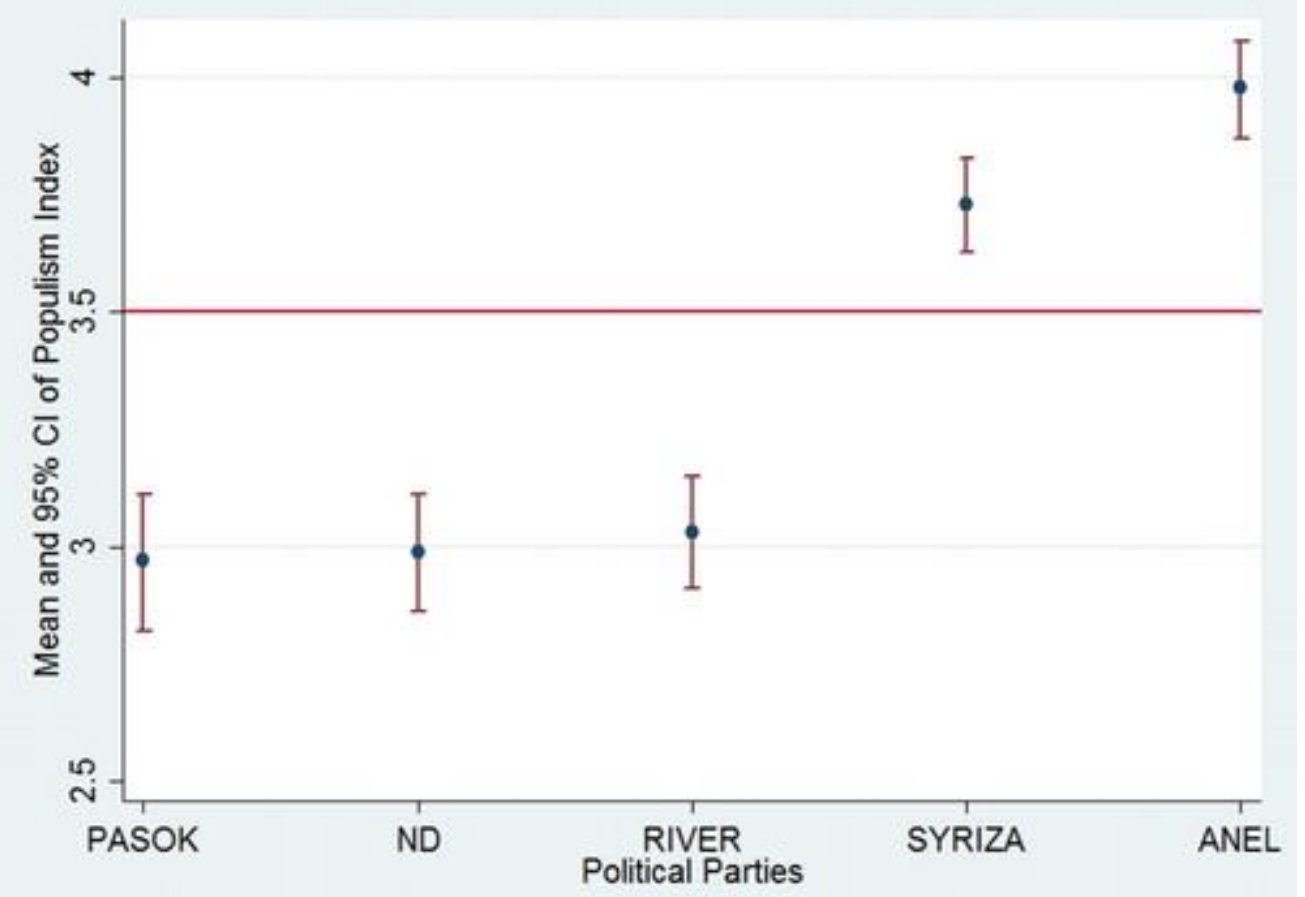

